\title{
Aggregate Index of Institutional Trust in Financial Institutions as a Method of Assessing the Development of the Russian Economy Institutional Environment
}

\author{
Zhelaeva S.E.* \\ East-Siberian State University of Technology and \\ Management \\ Ulan-Ude, Republic of Buryatia \\ e-mail: zhelay@yandex.ru
}

\author{
Ayurzanain A.B. \\ East-Siberian State University of Technology and \\ Management \\ Ulan-Ude, Republic of Buryatia \\ e-mail: ayurza9@yandex.ru
}

\author{
Darmaeva O.A. \\ East-Siberian State University of Technology and Management \\ Ulan-Ude, Republic of Buryatia \\ e-mail: oksana.smart@yandex.ru
}

\begin{abstract}
The article presents the analysis of trends in the development of the institutional environment of the economy of the Russian Federation. The article calculates the level of institutional deformation in the economy of the Russian Federation, which showed significant changes during the analyzed period from 2010 to 2014 , which may be partly due to a significant change in the global market and a number of successive financial and economic crises. The final stage of the study is the analysis of changes in the level of institutional trust of the population, which is based on a ten-factor model. The measurements of the level of institutional trust showed significant changes in the institutional trust of the population in financial institutions during the analyzed period 2008-2018.
\end{abstract}

Keywords - institutions, transaction costs, institutional environment, economic model, network economy, institutional deformation, network interactions, institutional trust.

\section{INTRODUCTION}

The world economic crisis marked a change in the paradigm of world development - the transition from the industrial mode of production to the post-industrial, as well as from capitalist society to post-capitalist [2]. This civilizational shift is caused by the combined action of three factors globalization, the scientific and technological revolution and the intensive development of social communications associated with the spread of Internet technologies. Mass online contacts reset social distances, which led to a sharp increase in the dynamism of the environment, the level of interdependence of players [3]. Rigid hierarchical structures are everywhere replaced by flexible network structures and form the institutional environment of the modern economy in a new way.

The peculiarity of the institutional environment of the economy of modern Russia is the dominance of imported institutions of a developed market economy with the abolition of previously quite effective institutions in favor of institutional changes.

In theory, there are two main ways of institutional change: evolutionary and revolutionary. As a result of the study it was found that the development and transformation of the social sphere of Russia took place mainly in a revolutionary way. The revolutionary way of institutional change is understood as the import of formal institutions that have already proved their effectiveness.

In Russia, the import of institutions comes mainly from other countries. Often the import of institutions, well established themselves in other countries, leads to negative results under the new conditions. In the Russian practice of importing institutions, the situation can lead to the emergence of if a viable institution, then ineffective and significantly different from the original. The reason for this phenomenon is the negative impact of institutional environment deformations.

Based on the definition of the institutional environment as a set of formal and informal institutions that regulate the choice of economic agents, as well as mechanisms to ensure the fulfillment of contractual obligations by its participants, it is necessary to consider the concept of deformation of the institutional environment [7]. In turn, the deformation of the institutional environment should be defined as the failure or ineffective performance of its components imputed functions (regulatory, regulatory, restrictive, stimulating, prohibiting, etc.), which is reflected in the growth of transaction costs.

\section{RESULTS AND DISCUSSION}

Adapting to the new conditions, economic agents modify the rules and norms of their behavior and, in a new way, forming the institutional environment, move to the cluster structure and the network method of coordination. Although inter-firm and inter-organizational network interactions in the 
modern economy have already received considerable coverage in the works of Russian scientists [4, 23, 30, 34], the relationship of cluster-network structure with the mechanism of innovative growth and economic growth as a whole is poorly studied. The wave of interest in this issue began to rise in the world of science is relatively recent, not only in the field of institutional Economics, but also in the field of sociology, management and economic theory [1]. Research in this area is of an in-depth interdisciplinary nature. The basis of this research is the position of the network economy as a field of research and institutional Economics.

The definitions of the essence of network and hierarchical interactions in the modern economic literature are diverse. It is considered that the network assumes horizontal communication, while the hierarchy is vertical. The analysis of the development of hierarchies and networks conducted by a number of economists, among which should be highlighted A. Gritsenko (2007) and V. Tarasevich (2005). Also, on one side there is the issue of the relevance of institutions and social networks, the presence of which clearly can be stated, based on the work of economist V. Dementieva (2008) investigating the views of M. Granoveter, John. Knight and other leading representatives of neo-institutionalism.

M. Castels exploring and highlighting the principles of functioning and development of network interactions in the economy the main feature of the modern information society notes the widespread use of information technology, the dominance of information, and the network logic of its use. Thus, Castells emphasizes the organic link between the new technological paradigm and the formation of the network structure and notes that the basis of the organization of the modern economy are network information flows, network structures and network interactions.

In this study, the authors emphasize the thesis of M. Castells that the modern economy is spontaneously transformed into a network system and thus becomes a "continuously flowing space of flows", gaining the ability of continuous updates [6].

At the beginning of the study it is necessary to determine the main forms of deformation of the institutional environment (table 1).

TABLE I.

SHAPE DEFORMATION OF THE INSTITUTIONAL ENVIRONMENT

\begin{tabular}{|c|c|c|}
\hline Deformation form & Example & Influence \\
\hline $\begin{array}{l}\text { Contradiction between system- } \\
\text { forming and auxiliary } \\
\text { institutions. }\end{array}$ & $\begin{array}{l}\text { The system-forming institutions are the normative legal } \\
\text { norms regulating the financial sector. } \\
\text { Auxiliary institutions - customs of business turnover. }\end{array}$ & $\begin{array}{l}\text { It finds expression in the increase in the share of the shadow } \\
\text { sector of the economy in total income. }\end{array}$ \\
\hline $\begin{array}{l}\text { Contradiction between normative } \\
\text { and positive content of } \\
\text { institutions. }\end{array}$ & $\begin{array}{l}\text { Normative content - the content of the designed institutions. } \\
\text { Positive content - the content of real institutions. }\end{array}$ & $\begin{array}{l}\text { It finds expression in the rent-oriented behavior of the } \\
\text { bureaucracy, the volume and share of the status rent (issue } \\
\text { income, income from the provision of public services, etc.) in } \\
\text { the total volume of consolidated budget revenues. }\end{array}$ \\
\hline $\begin{array}{l}\text { The contradiction between } \\
\text { existing and projected } \\
\text { institutions. }\end{array}$ & $\begin{array}{l}\text { The design of the institutions to be imported, newly created, } \\
\text { transformed institutions. }\end{array}$ & $\begin{array}{l}\text { It is manifested in indicators of innovative activity of } \\
\text { economic agents (share of innovative products in total } \\
\text { income, etc.) }\end{array}$ \\
\hline $\begin{array}{l}\text { The presence of persistent } \\
\text { inefficient institutions. }\end{array}$ & $\begin{array}{l}\text { Institutions of corruption, institutions of the shadow } \\
\text { economy, institutions of drug trafficking, etc. }\end{array}$ & $\begin{array}{l}\text { It manifests itself in a negative impact on the economy and } \\
\text { society. }\end{array}$ \\
\hline $\begin{array}{l}\text { The contradiction between local, } \\
\text { national and global institutions. }\end{array}$ & Inconsistency between national and international law & $\begin{array}{l}\text { It is manifested in the dynamics of the main economic and } \\
\text { social indicators. }\end{array}$ \\
\hline $\begin{array}{l}\text { The contradiction between the } \\
\text { transformational and } \\
\text { transactional sectors of the } \\
\text { economy. }\end{array}$ & $\begin{array}{l}\text { A significant excess of the rate of development of the } \\
\text { financial sector of the economy over the rate of development } \\
\text { of the real sector, the autonomy of financial capital from the } \\
\text { real sector of the economy. }\end{array}$ & $\begin{array}{l}\text { It is reflected in economic crises, rising inflation and } \\
\text { unemployment. }\end{array}$ \\
\hline $\begin{array}{l}\text { Increasing heterogeneity of the } \\
\text { institutional environment. }\end{array}$ & The difference in the density and intensity of transactions. & It manifests itself in the polarization of the economic space. \\
\hline
\end{tabular}

It is necessary to note that the degree of heterogeneity is increasing in States with a Federal structure, due to the presence in the institutional environment of a significant number of institutions of a local nature. Indicators of such deformations are the ratio of economic and social indicators that reflect the state of individual geographically localized entities (regions, municipalities) that are part of the state, as well as indicators of income differentiation, etc.

According to modern economists, institutional trust is one of the basic elements that make possible market exchange, since any long-term transaction requires faith in various kinds of promises [20, 21]. With the ever-increasing complexity and differentiation of market transactions in global society, there is an increasing need for further development of institutions aimed at building market trust between producers and consumers [2].
In the case of financial institutions, institutional trust implies the existence of legislative mechanisms to regulate activities and their actual use as a tool to protect the implementation of formal rules or contracts. A society with a high level of trust will be less likely to resort to vertical integration to guarantee specific investments than a society with a low level of trust [9].

If we consider the institutional environment in which transactions are carried out and the factors that influence the choice of the form of the contract, it can be noted that the institutional environment has a great influence on the choice of the form of the contract and primarily on the need for certain guarantees in the implementation of specific investments $[12,22]$ Transactions that are executed in one institutional environment may not be viable in another [11]. 
The Procedure for calculating the aggregate institutional trust index is based on an assessment of the balance between positive and negative assessments. For each question, a private index is calculated - the share of negative answers is subtracted from the share of positive answers and 100 is added to this difference in order to exclude negative values. The aggregate index is equal to the average of private indices and characterizes the change in trust in financial institutions as a whole. In addition to the aggregate index are calculated: the index of the current situation, which is equal to the average of the indices of reliability and transparency for the past year, as well as the index of profitability of investments; the index of expectations, which is equal to the average of the indices of reliability and transparency in the coming year. Index values, both General and private, can range from 0 to 200.

TABLE II. CALCULATION OF THE AGGREGATE INDEX OF INSTITUTIONAL TRUST IN FINANCIAL INSTITUTIONS

\begin{tabular}{|l|l|l|l|l|l|l|l|l|}
\hline \multicolumn{1}{|c|}{ Index } & $\mathbf{2 0 0 8}$ & $\mathbf{2 0 0 9}$ & $\mathbf{2 0 1 0}$ & $\mathbf{2 0 1 1}$ & $\mathbf{2 0 1 2}$ & $\mathbf{2 0 1 6}$ & $\mathbf{2 0 1 7}$ & $\mathbf{2 0 1 8}$ \\
\hline $\begin{array}{l}\text { Assessment of the } \\
\text { reliability of financial } \\
\text { institutions over the past } \\
\text { year* }\end{array}$ & 91 & 76 & 82 & 89 & 95 & 98 & 98 & 97 \\
\hline $\begin{array}{l}\text { Expectations of reliability } \\
\text { of financial institutions in } \\
\text { the coming year* }\end{array}$ & 97 & 83 & 92 & 101 & 101 & 103 & 102 & 101 \\
\hline $\begin{array}{l}\text { Assessment of } \\
\text { transparency of financial } \\
\text { institutions in the past } \\
\text { year* }\end{array}$ & 103 & 88 & 89 & 93 & 98 & 97 & 93 & 92 \\
\hline $\begin{array}{l}\text { Expectations of } \\
\text { transparency of financial } \\
\text { institutions in the coming } \\
\text { year* }\end{array}$ & 101 & 89 & 92 & 95 & 100 & 99 & 96 & 96 \\
\hline $\begin{array}{l}\text { Assessment of profitability } \\
\text { of financial investments* }\end{array}$ & 95 & 84 & 90 & 92 & 91 & 98 & 99 & 97 \\
\hline $\begin{array}{l}\text { The current situation } \\
\text { index* }\end{array}$ & 96 & 83 & 87 & 91 & 95 & 98 & 97 & 95 \\
\hline The expectations index* & 99 & 86 & 92 & 98 & 101 & 101 & 99 & 99 \\
\hline $\begin{array}{l}\text { Index of successful } \\
\text { activity of financial } \\
\text { institutions }\end{array}$ & 183 & 180 & 177 & 176 & 173 & 172 & 172 & 171 \\
\hline $\begin{array}{l}\text { The index of disclosure of } \\
\text { financial crimes** }\end{array}$ & 110 & 110 & 110 & 110 & 110 & 110 & 110 & 110 \\
\hline $\begin{array}{l}\text { The index of demand for } \\
\text { financial services }\end{array}$ & 41 & 44 & 44 & 47 & 53 & 54 & 56 & 59 \\
\hline $\begin{array}{l}\text { Total trust in financial } \\
\text { institutions }\end{array}$ & 102 & 92 & 96 & 99 & 102 & 103 & 102 & 102 \\
\hline
\end{tabular}

In our proposed additional three factors calculations are made as follows:

1) the index of the successful activities of financial institutions $=$ the Percentage of the existing financial institutions - the Share of financial institutions on which the decision on the elimination of +100 ;

2) the index of disclosure of financial crimes $=$ the Proportion of crimes solved - the Share of unsolved crimes +100 ;

3) the index of demand for financial services $=$ the Share of income of the population in the accounts of financial institutions - the Share of income +100 .
The index of successful activity of financial institutions shows the state of the financial industry in the country, reflecting the number of financial institutions that failed to fulfill their obligations to the population. This will undoubtedly affect the institutional trust of the population in the future, which confirms the feasibility of including this indicator in the calculation methodology.

The financial crime disclosure index reflects the shadow segment of the financial sector and its corruption. With a negative characteristic of this indicator, the population will believe that financial institutions are dishonest in carrying out operations with their financial assets, which will affect the decline in institutional trust.

The index of demand for financial services reflects the demand for financial services among the population, which to some extent reflects the level of institutional trust in financial institutions. The population with a low level of trust will keep the money "on hand", refraining from using financial services.

The calculations carried out for the period 2008-2018 showed that the aggregate index of institutional trust changed significantly and the minimum value of the index was recorded in March 2009 (Fig. 1).

It is important to note that the institutional trust of the population in financial institutions (measured in this case on the basis of indices) significantly affects the number of transactions and contracts in the financial market. This, in turn, had a significant impact on the development of negative crisis consequences for the country's economy.

\section{Conclusions}

The article analyzes and considers the trends in the development of the institutional environment of the financial market of the Russian Federation at the present stage. According to the results of the study, it should be noted the increasing role of network interactions both in the world economy and in the Russian economy.

Financial market institutions play a leading role in shaping the modern architecture of the modern economy. In this regard, the study of the institutional environment in this sector is of additional interest to the scientific community.

Forming conclusions on the theoretical part of the article it should be noted the importance of imported institutions and as a consequence of the emerging complex economic phenomenon - institutional deformation. In the theoretical part of the classification of institutional deformations using specific examples. This gives us the opportunity for a more accurate analysis of the institutional environment of the modern financial market, which is formed under the complex influence of many economic factors. In the end, consideration of this issue helps us to understand why the same financial institution or norm is taking root and successfully functioning in certain economies, and in others, on the contrary, are recognized as ineffective.

Another important aspect is the typology of network interactions in the modern economic system on the basis of retrospective analysis. Network interactions between 
economic agents are present one way or another in any economic system. In General, it can be concluded that the quality and quantity of network interactions in the economic system to some extent forms the level of its development.
More developed economic systems are characterized by a greater number of network-type economic relations with different levels of market power on the one hand and the number of network interactions on the other.

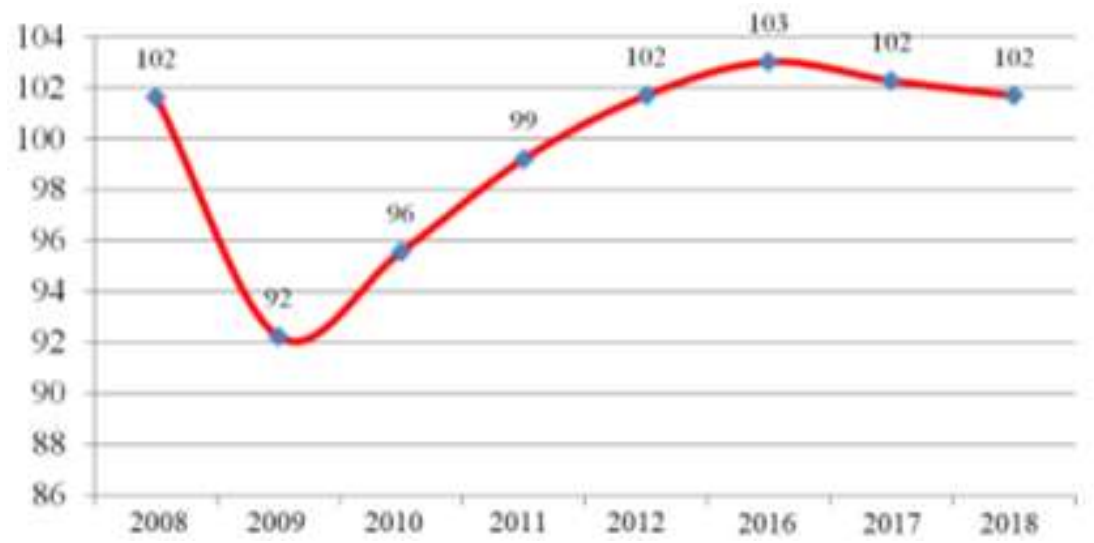

Fig. 1. Dynamics of the aggregate index of institutional trust in financial institutions. Source: Compiled by the author

The final, but no less important aspect of this study is the study of the dynamics of the level of institutional trust of the population in financial institutions, which in fact has a direct impact on the quality and development of monetary exchange in the economic system. The study showed that the level of institutional trust was measured on the basis of grouping and calculation of 10 factors, the value of the level of institutional trust is quite a highly variable over time. It is important to note that, for example, the impact of the financial and economic crisis had a negative impact on the level of institutional trust of the population, which faced bankruptcy and subsequent withdrawal from the market of large banking institutions that could not meet the new economic conditions, comply with the standards of the Central Bank of Russia and so on.

According to the results, it is important to note that the development of network interactions, we examined by analyzing the activities of financial institutions of the Russian Federation for today is crucial for the whole economic system of the state.

\section{References}

[1] J.E. Anderson, E. Van Wincoop, "Trade costs", J. of Econ. literat., vol. 42, no. 3, pp. 691-751, 2004.

[2] A.B. Ayurzanain, "Institutional changes in the Russian economy in modern conditions of the influence of external factors and restrictions", Econ. sci., no. 131. pp. 7-13, 2011.

[3] A.B. Ayurzanain, "The institutional environment of the economy of the Russian Federation at the present stage: analysis of trends and development prospects", no. 2, pp. 10-18, 2015 [Socio-economic development of Russia and Mongolia: problems and prospects: materials of the IV Intern. scientific-practical conf.]. Ulan-Ude.

[4] N.V. Basov, "Innovation as a factor of social self-organization: processspatial modeling", J. of social. and soc. Anthropol., vol. XI, no. 4, pp. 185-203, 2008.

[5] R. Bernhard, Network theory, In: The Politics of Systems, 2014, pp. 196-200.

[6] M. Castels, Information age: economy, society and culture. Moscow: HSE, 2000, pp. 185-203.

[7] R.H. Coase, "The Nature of the Firm", Econ., no. 4, pp. 386-405, 1937.
[8] S.V. Dementieva, "Russian Universities as a mechanism of adaptation of educational migrants (in the context of sociological and philosophical analysis)", Proc. of Tomsk Polytech. Univer., Engineer. of georesources, vol. 313, no. 6, pp. 169-178, 2008.

[9] D. Winch, W.J. Samuels, "The Classical Theory of Economic Policy", The Econ. J., vol. 77, iss. 307, pp. 640-641, 1 September 1967.

[10] P. Draker, Post-Capitalist society, In: New post-industrial wave in the West. The anthology, under the editorship of V.L. Inozemtsev. Moscow: Academia, 1999, pp. 70-100.

[11] T.H. Eriksen, Tyranny of the Moment: Fast and Slow Time in the Information Age. London: Pluto Press, 2001, pp. 98-103.

[12] L.A. Fennell, "Ostrom's Law: Property rights in the Commons", Int. J. of the Commons, vol. 5, no. 1, pp. 9-27, 2011.

[13] A.A. Gritsenko, Hierarchy and network structure in the institutional architecture of economic systems, 2007, pp. 38-49.

[14] R. Greenwood et al. (ed.), The Sage handbook of organizational institutionalism. Sage, 2017, pp. 19-27.

[15] G.M. Hodgson, Institutional economics. Rethinking Economics. Routledge, 2017, pp. 59-73.

[16] G.M. Hodgson, "Institutional economics into the twenty-first century", Studi e Note di Economia, vol. 14, no. 1, pp. 3-26, 2009.

[17] D.C. North et al., Violence and social orders: A conceptual framework for interpreting recorded human history. Cambridge: Cambridge Univer. Press, 2009, pp. 65-75.

[18] R.M. Nureyev, "Methodological background of modern economic theory (Economics): development trends", Sci. papers of Donetsk National Techn. Univer., Ser. Econ., no. 1, pp. 5-18, 2014.

[19] K. Orren, S. Skowronek, "Beyond the iconography of order: notes for a "new institutionalism"', The dynamics of American politics, pp. 311-330, 2018.

[20] B.G. Peters, Institutional theory in political science: The new institutionalism. Edward Elgar Publ., 2019, pp. 181-202.

[21] J.P. Platteau, Institutions, social norms and economic development. Routledge, 2015, pp. 181-202.

[22] W.W. Powell, P.J. DiMaggio, The new institutionalism in organizational analysis. Univer. of Chicago press, 2012, pp. 193-202.

[23] S.I. Record, Development of industrial and innovative clusters in Europe: evolution and modern discussion, 2010, pp. 163-169.

[24] S.I. Arkhireev, "Institutional interactions as a basis of network interactions and problems of post-transformation market economy", J. of Institut. Studies, no. 1, pp. 176-179, 2012. 
[25] V.A. Schmidt, "Taking ideas and discourse seriously: explaining change through discursive institutionalism as the fourth "new institutionalism"”, Europ. political sci. rev., vol. 2, no. 1, pp. 1-25, 2010.

[26] W.R. Scott, Institutions and organizations: Ideas and interests. Sage, 2008, pp. $150-159$.

[27] S. Slaughter, S.A. Slaughter, G. Rhoades, Academic capitalism and the new economy: Markets, state, and higher education. JHU Press, 2004, pp. 237-249.

[28] A. Shastitko, C. Ménard, "Discrete institutional alternatives Theoretical and policy issues (Celebrating the 80th anniversary of Ronald Coase's "Nature of the Firm")", Russ. J. of Econ., vol. 3, no. 2, pp. 200-220, 2017.

[29] A.E. Shastitko, I.P. Shabalov, I.N. Filippova, "Institutions and production material-intensity: A new look at the old problem", Vopr. Ekon., no. 2, pp. 74-94, 2018.
[30] A.E. Shastitko, "Clusters as a form of spatial organization of economic activity: problem theory and empirical observations", Baltic reg., no. 2, pp. 84-89, 2010.

[31] P.L. Siklos, "Central Bank Transparency: Another Look", CAMA Work. Paper, no. 23/2010, pp. 45-94, 2010.

[32] D. Tapscott, A.D. Williams, "Innovating the 21 st-century university: It's time", Educause rev., vol. 45, no. 1, pp. 16-29, 2010.

[33] V.N. Tarasevich, Institutional theory: methodological research and the hypotheses necessary, In: Post-Soviet institutionalism, vol 480, ed. by R.M. Nureyev, B.B. Dementieva. Donetsk: Chestnut, 2005, pp. 30-48.

[34] O.A. Tretyak, M.N. Rumyantseva, "Network forms of inter-firm cooperation: approaches to explaining the phenomenon", Russ. J. of manag., vol. 1, no. 2, pp. 35-45, 2003.

[35] O.E. Williamson, E. Brousseau, J.M. Glachant, The New Institutional Economics Guidebook, New Institutional Economics, 2008, pp. 181-202. 